\title{
Chapter 16 \\ Smartforests Canada: A Network \\ of Monitoring Plots for Forest \\ Management Under Environmental \\ Change
}

\author{
Christoforos Pappas, Nicolas Bélanger, Yves Bergeron, Olivier Blarquez, \\ Han Y. H. Chen, Philip G. Comeau, Louis De Grandpré, Sylvain Delagrange, \\ Annie DesRochers, Amanda Diochon, Loïc D'Orangeville, Pierre Drapeau, \\ Louis Duchesne, Elise Filotas, Fabio Gennaretti, Daniel Houle, Benoit Lafleur, \\ David Langor, Simon Lebel Desrosiers, Francois Lorenzetti, Rongzhou Man, \\ Christian Messier, Miguel Montoro Girona, Charles Nock, Barb R. Thomas, \\ Timothy Work, and Daniel Kneeshaw
}

\begin{abstract}
Monitoring of forest response to gradual environmental changes or abrupt disturbances provides insights into how forested ecosystems operate and allows for quantification of forest health. In this chapter, we provide an overview of Smartforests Canada, a national-scale research network consisting of regional investigators who support a wealth of existing and new monitoring sites. The objectives of Smartforests are threefold: (1) establish and coordinate a network of high-precision monitoring plots across a $4400 \mathrm{~km}$ gradient of environmental and forest conditions, (2) synthesize the collected multivariate observations to examine the effects of global changes on complex above- and belowground forest dynamics
\end{abstract}

C. Pappas $(\varangle) \cdot$ N. Bélanger $\cdot$ E. Filotas $\cdot$ S. Lebel Desrosiers

Centre d'étude de la forêt, Université du Québec à Montréal, Montréal, QC, Canada

Département Science et Technologie, Téluq, Université du Québec, Montréal, QC, Canada e-mail: christoforos.pappas@teluq.ca

Y. Bergeron · A. DesRochers

Centre d'étude de la forêt, Université du Québec à Montréal, Montréal, QC, Canada

Forest Research Institute, Université du Québec en Abitibi-Témiscamingue,

Amos, QC, Canada

O. Blarquez

Département de Géographie, Université de Montréal, Montréal, QC, Canada

H. Y. H. Chen

Faculty of Natural Resources Management, Lakehead University, Thunder Bay, ON, Canada

P. G. Comeau · C. Nock · B. R. Thomas

Department of Renewable Resources, University of Alberta, Edmonton, AB, Canada

R. Tognetti et al. (eds.), Climate-Smart Forestry in Mountain Regions, Managing

Forest Ecosystems 40, https://doi.org/10.1007/978-3-030-80767-2_16 
and resilience, and (3) analyze the collected data to guide the development of the next-generation forest growth models and inform policy-makers on best forest management and adaptation strategies. We present the methodological framework implemented in Smartforests to fulfill the aforementioned objectives. We then use an example from a temperate hardwood Smartforests site in Quebec to illustrate our approach for climate-smart forestry. We conclude by discussing how information from the Smartforests network can be integrated with existing data streams, from within Canada and abroad, guiding forest management and the development of climate change adaptation strategies.

\author{
L. De Grandpré \\ Natural Resources Canada, Canadian Forest Service, Laurentian Forestry Centre, \\ Quebec City, QC, Canada
}

S. Delagrange $\cdot$ F. Lorenzetti $\cdot$ C. Messier

Centre d'étude de la forêt, Université du Québec à Montréal, Montréal, QC, Canada

Institut des Sciences de la Forêt Tempérée (ISFORT), Université du Québec en Outaouais (UQO), Ripon, QC, Canada
A. Diochon
Department of Geology, Lakehead University, Thunder Bay, ON, Canada
L. D'Orangeville
Faculty of Forestry and Environmental Management, University of New Brunswick, Fredericton, NB, Canada

P. Drapeau · T. Work · D. Kneeshaw

Centre d'étude de la forêt, Université du Québec à Montréal, Montréal, QC, Canada

Département des sciences biologiques, Université du Québec à Montréal,

Montréal, QC, Canada

L. Duchesne

Direction de la Recherche Forestière, Ministère des Forêts, de la Faune et des Parcs du Québec, Quebec City, QC, Canada

F. Gennaretti · B. Lafleur

Forest Research Institute, Université du Québec en Abitibi-Témiscamingue,

Amos, QC, Canada

D. Houle

Science and Technology Branch, Environment and Climate Change Canada,

Montreal, QC, Canada

D. Langor

Natural Resources Canada, Canadian Forest Service, Edmonton, AB, Canada

R. Man

Ontario Forest Research Institute, Ontario Ministry of Natural Resources and Forestry, Sault Ste. Marie, ON, Canada

M. M. Girona

Forest Research Institute, Université du Québec en Abitibi-Témiscamingue,

Amos, QC, Canada

Restoration Ecology Group, Department of Wildlife, Fish and Environmental Studies, Swedish University of Agricultural Sciences, Umeå, Sweden 


\subsection{Introduction}

Canada is the third most forested country in the world with 347 million ha of forest land (The State of Canada's Forests 2020). This vast forest provides habitat for flora and fauna as well as crucial ecological, social, and economic services. Canadian forests contribute over $\$ 25$ billion to Canada's gross domestic product and directly employ ca. 210,000 people in the forest industry (The State of Canada's Forests 2020). In addition to these direct economic benefits, forests provide critical ecological, social, and spiritual services. Furthermore, Canadian forests play a key role in the global carbon balance and thus affect Canada's international commitments regarding net carbon emissions (Luyssaert et al. 2008; Pan et al. 2011; Le Quéré et al. 2018; Baldocchi and Penuelas 2019).

However, the sustainability and resilience of forests are increasingly threatened by climate change as well as natural and anthropogenic disturbances, especially in high-latitude forests (ACIA 2005; Soja et al. 2007; Brandt et al. 2013; Gauthier et al. 2015; Trumbore et al. 2015; Brecka et al. 2020; DeSoto et al. 2020). Climate change will cause gradual long-term changes as well as increased frequency and severity of extreme events. These changes will contribute to increased uncertainty about future forest conditions that threaten the long-term viability of the forest sector and of human well-being (IPCC 2013; Brecka et al. 2020). Warming climate, drought stress, increasing frequency and severity of wildfires, and unprecedented outbreaks of insects and diseases are expected to reduce forest productivity and dramatically change forest composition, with concomitant impacts on biodiversity and ecosystem function, including the net carbon balance (Seidl et al. 2017; Navarro et al. 2018; Pugh et al. 2019).

While Canadian forest landscapes have always been dynamic due to the influence of a wide variety of natural biotic and abiotic disturbances, recent global changes are likely to alter the frequency and severity of these disturbances and lead to new disturbances not previously encountered. Increases in mean annual air temperature of $2.0{ }^{\circ} \mathrm{C}$ have been reported in western Canada during the period 1950-2003, compared with increases of only $0.5^{\circ} \mathrm{C}$ in eastern Canada (Price et al. 2013). Similar discrepancies in precipitation have also been observed between eastern and western regions of Canada. In some areas, drought stress will reduce forest productivity and could threaten many ecosystem services. Given the vast extent of Canadian forests, effects of climate change will vary with geographic location, topography, forest composition, and local conditions. For example, western boreal forests are already drier than eastern boreal forests. Thus, slight increases in temperature or small decreases in precipitation may cause drought stress, reduced growth, increased tree mortality, and shifts in tree species composition, particularly in species-poor forests in western regions (Hogg et al. 2008; Michaelian et al. 2011; Peng et al. 2011; Chen et al. 2017; Cortini et al. 2017; Hisano et al. 2017; Searle and Chen 2017; Pappas et al. 2018). Another example is novel insect outbreaks, such as the invasion of the western boreal forest by the mountain pine beetle (Safranyik et al. 2010). However, in eastern boreal forests, warmer and drier conditions may 
increase tree growth (D'Orangeville et al. 2016, 2018). Several studies point toward a positive effect of the increased concentration of atmospheric $\mathrm{CO}_{2}$ on tree growth (e.g., Tagesson et al. 2020), but reverse patterns have also been reported (Girardin et al. 2016). Translating how a carbon source (i.e., photosynthesis) is converted to a tree carbon sink (i.e., growth) remains challenging (Fatichi et al. 2019; Walker et al. 2020). Regional variation in forest responses to air temperature or precipitation change is also expected along a North-South gradient (Huang et al. 2010; Hogg et al. 2013; Chen et al. 2017). Projected increases in atmospheric $\mathrm{CO}_{2}$ concentration, air temperature, evaporative demand, and surface net radiation are expected to intensify climate extremes, such as atmospheric and soil droughts (Held and Soden 2006; Dai 2012; Cook et al. 2014), with pronounced commensurate impacts on forest composition, structure, and function (Allen et al. 2015; Novick et al. 2016). Site-specific conditions will shape the impacts of climate change on forest function. Management options should be tailored accordingly by implementing case-specific solutions. Changes in soil conditions (nutrient concentrations, organic layer, permafrost) could scale up to long-term losses in productivity. Similarly, shifts in phenology can alter the synchrony between tree hosts and insect pests, potentially leading to increased damage to trees (Pureswaran et al. 2015). As a result, small-scale changes can have large consequences for forests, particularly when conditions are close to critical thresholds (Allen et al. 2015; Reyer et al. 2015; Trumbore et al. 2015).

Climate-smart forestry in the era of rapidly changing environmental conditions should provide tailored solutions for sustainable forest management based on a mechanistic understanding of forest function and of the influence of environmental stressors (Bowditch et al. 2020; Verkerk et al. 2020). This can be achieved by collecting and analyzing multivariate and multiscale observations of forest function (e.g., from the cell to the organism and to the ecosystem level) together with advanced understanding and numerical modelling of processes. Forest monitoring thus plays a central role in providing data to: (i) build improved knowledge on forest function at multiple spatiotemporal scales, as well as forest health and resilience to environmental change, and (ii) design and validate predictive modelling through numerical experiments. Precise temporal data, which are representative of the dynamic responses of forests in real time, are crucial for understanding and predicting the effects of global change (Kayler et al. 2015; Sass-Klaassen et al. 2016; Steppe et al. 2016). Accurate forest modelling, with state-of-the-art process-based simulation tools, allows for hypothesis testing and evaluating risk and uncertainty by conducting numerical experiments with hypothetical, yet realistic, scenarios of future climate conditions and/or forest stand composition (Fatichi et al. 2016; Mencuccini et al. 2019; Mastrotheodoros et al. 2020). To ensure the long-term viability of the forest sector, we also need well-coordinated research efforts that span a wide range of forest ecosystems and climatic conditions. While there have been many local-scale studies of changes associated with climate, we are lacking a comprehensive understanding of ecological responses and how these vary across the major forest types in Canada. We urgently need a Canada-wide concerted effort to document effects of climate variability, to experiment with different species mixes, and to model forest responses across large climatic gradients and forest types. 
Smartforests Canada (https://smartforest.uqam.ca/) is a national project designed to address this gap through the establishment of a Canada-wide network of monitoring sites covering a wide spectrum of forest biomes and environmental conditions. More specifically, Smartforests aims to provide an improved understanding of how ecosystems, species, populations, and individual trees are influenced by changes in both physical (climate, soil) and biotic (competition, facilitation) environmental factors as well as interactions between these factors. The objectives of Smartforests are threefold: (1) establish a network of high-precision forest monitoring plots across a gradient of forest types and environmental conditions to examine the effects of global changes on complex above- and belowground forest dynamics, (2) synthesize multivariate data collected across the monitored forest stands to assess ecosystem functioning and resilience, and (3) assimilate the data and understanding of processes to guide the development of the next generation of forest growth simulation models and inform policy-making toward the best management and adaptation strategies for our forests.

In this chapter, we provide an overview of the Smartforests methodological approach and network of sites, and illustrate this multivariate and cross-scale Smartforests framework with an example of a temperate hardwood forest site in Quebec, Canada. We conclude with an outlook on how the Smartforests toolbox, based on state-of-the-art technology with automated and campaign-based measurements, can be deployed to quantify the multifaceted aspects of forest functioning and resilience under climate change. This holistic approach is firmly based on a balanced experimental design, which includes belowground, understory, and overstory forest components as well as biotic and abiotic factors affecting forest function. Information from the multivariate, multilevel Smartforests data streams can be integrated with global observation networks, where Canadian forests are currently underrepresented, and can be used for advanced forest growth modelling to guide forest management and the development of climate change adaptation strategies.

\subsection{Methodological Framework}

\subsubsection{High-Precision Monitoring Plots}

The backbone of the Smartforests approach is based on a Canada-wide network of high-precision forest monitoring plots (Fig. 16.1). These plots are designed to provide intensive and detailed spatiotemporal data on meteorological and soil conditions as well as various forest functions that are necessary to understand the response of forests to environmental stressors (Fig. 16.2). A tree-centered approach underlies the experimental design and instrumentation (Sass-Klaassen et al. 2016). Detailed observations are collected at different levels of spatial organization, spanning from the cell (e.g., plant tissue) to the organism (e.g., tree), the forest stand, and the landscape, and include campaign-based but also automated observations, coupled with 


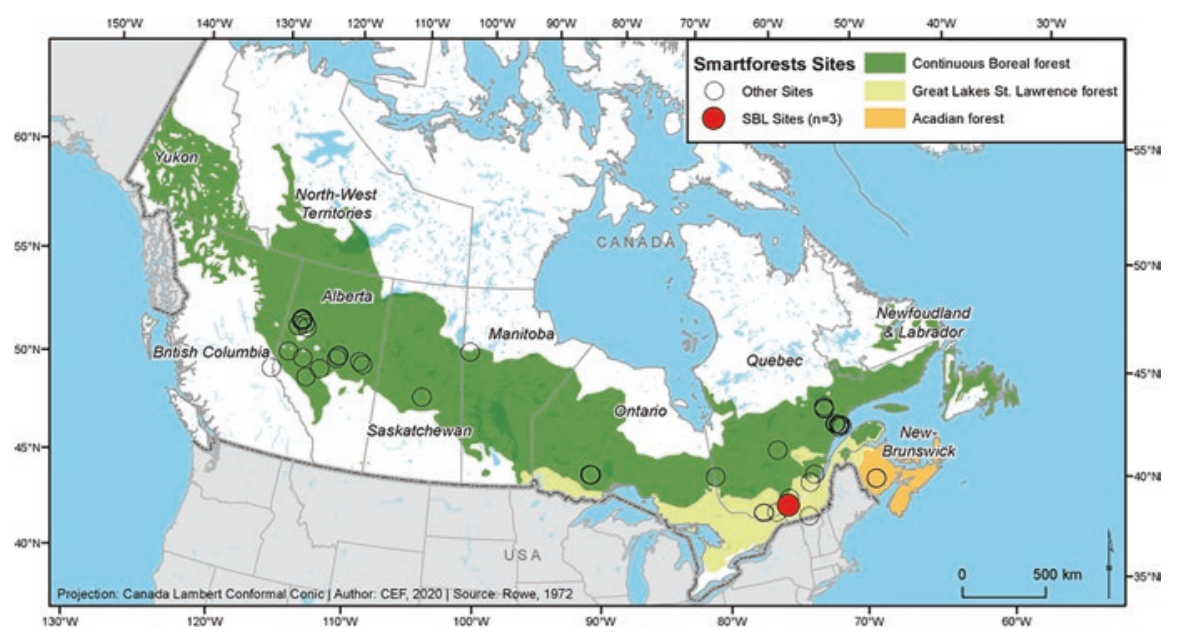

Fig. 16.1 An overview of the Smartforests network of sites. The strategically selected sites cover a wide range of environmental conditions as well as distinct forest types and vegetation characteristics. Point clusters occur in certain areas since, within each region, several monitoring plots are established to cover local-scale climatic gradients and environmental conditions. The case study used here to illustrate the implemented Smartforests approach is highlighted in red (Station de biologie des Laurentides; SBL)

remote sensing data (Fig. 16.2). It is important to underline that instrumentation and observed variables are not necessarily homogeneous across the network. Site-level priorities and specific research questions have resulted in tailored experimental designs to address the needs of specific research groups. Measured variables include meteorological (e.g., precipitation, air temperature, radiation, wind speed and direction, relative humidity) and soil conditions (temperature, water and nutrient availability), in addition to information on tree growth, reproduction, mortality, phenological changes in organisms, community turnover rates, net primary productivity, and trophic interactions. These high-precision monitoring plots allow us to: (1) collect long-term biological, ecological, and environmental data to document and understand changes in forest functioning with climate variability, (2) develop a network promoting ecological research and stimulating collaborations at national and international levels, and (3) provide a unique setting not only for research but also for educational activities, such as hosting teaching seminars, field classes, and facilitating student engagement through exposure to the scientific method.

The methodological design and the deployed instruments are tailored to cover a wide range of relevant ecophysiological and ecological processes and to quantify forest function including belowground as well as the understory and overstory components (Fig. 16.2). In the overstory, for example, we focus on measuring key biogeochemical processes describing the exchange of carbon, water, and energy in the soil-plant-atmosphere continuum, including measurements at the leaf level (e.g., leaf gas exchanges) and tree level (e.g., stem water fluxes and growth) but also at the landscape level (e.g., airborne thermal imaging), focusing on species interactions 


\section{(a) Smartforests Canada}

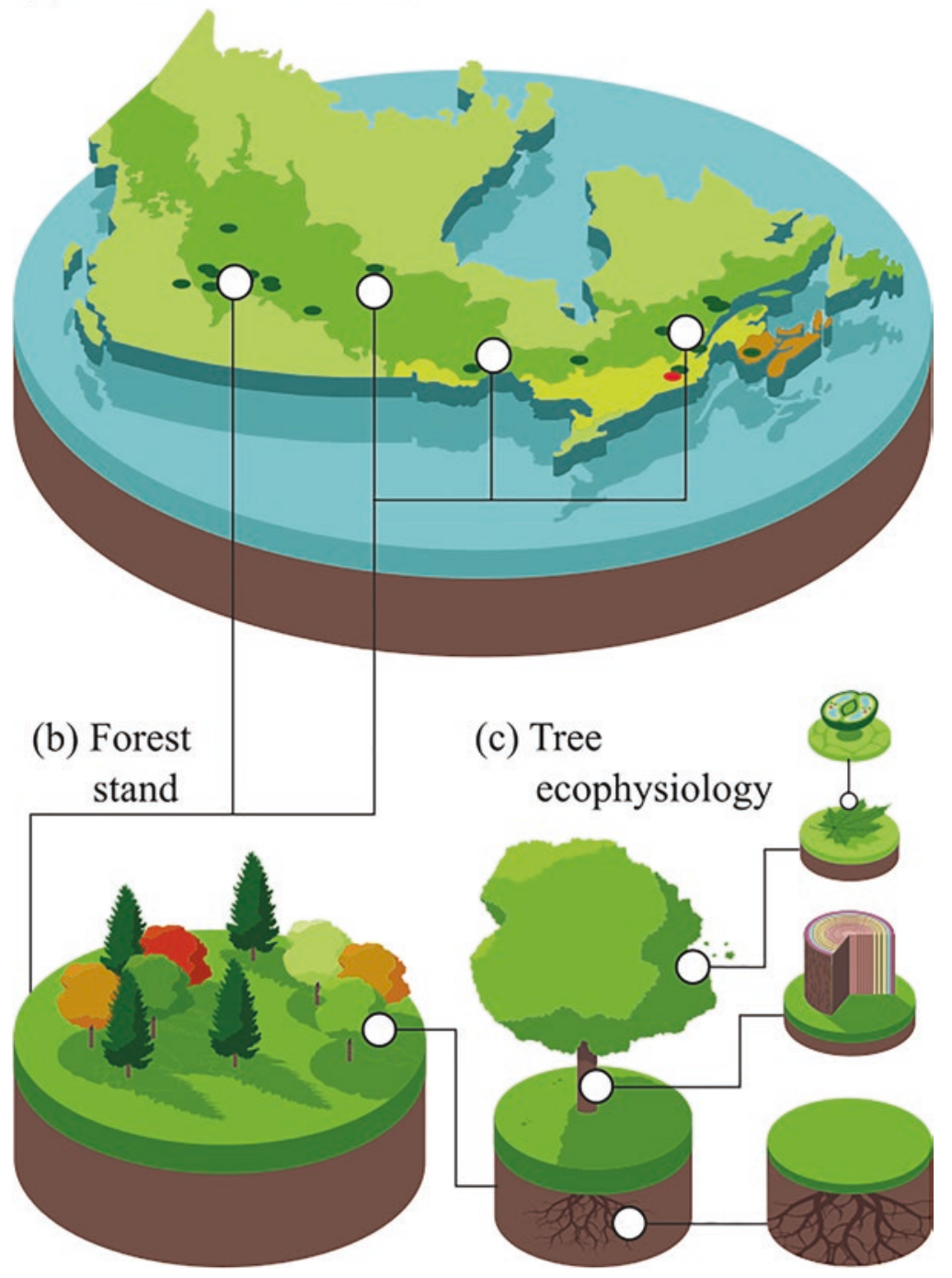

Fig. 16.2 The tree-centered approach implemented in the Smartforests network for tackling pressing environmental change questions in Canadian forests. Detailed tree ecophysiological observations are collected at the cell and whole plant level (subplot c). Plant ecophysiological insights and tree-level process understanding are upscaled to the forest stand level using information on stand demography and airborne imaging (subplot b). Findings at the forest stand level are synthesized across the Smartforests network of sites to better understand and model forest structure and function, health, and resilience to environmental change and provide Canada-wide guidance for forest management and policy-making (subplot a) 
(Fig. 16.2). Understory vegetation is also monitored to quantify species demography and growth dynamics (Landuyt et al. 2019). Finally, soil conditions and belowground processes (e.g., temperature, water and nutrient availability, fine root growth, soil respiration, litter decomposition) are also explicitly monitored, acknowledging the fundamental role of soil biogeochemistry and belowground processes to tree growth and forest health (Vicca et al. 2012; Clemmensen et al. 2013).

\subsubsection{The Smartforests Canada Network of Sites}

The Smartforests network includes more than 100 high-precision forest monitoring plots spread across Canada (Figs. 16.1 and 16.3). The research efforts at these sites are geared toward pressing environmental change questions, in accordance with the Smartforests objectives, yet instrumentation and specific research questions explored at each site may vary. These forest plots cover a wide range of environmental conditions and include major North American forest types with widespread common tree species. The established network spans a temperature gradient of about $8{ }^{\circ} \mathrm{C}$, i.e., mean annual air temperature across sites ranges from $-3{ }^{\circ} \mathrm{C}$ to $5{ }^{\circ} \mathrm{C}$. The gradient of monitoring plots covers forests from southern shade-tolerant

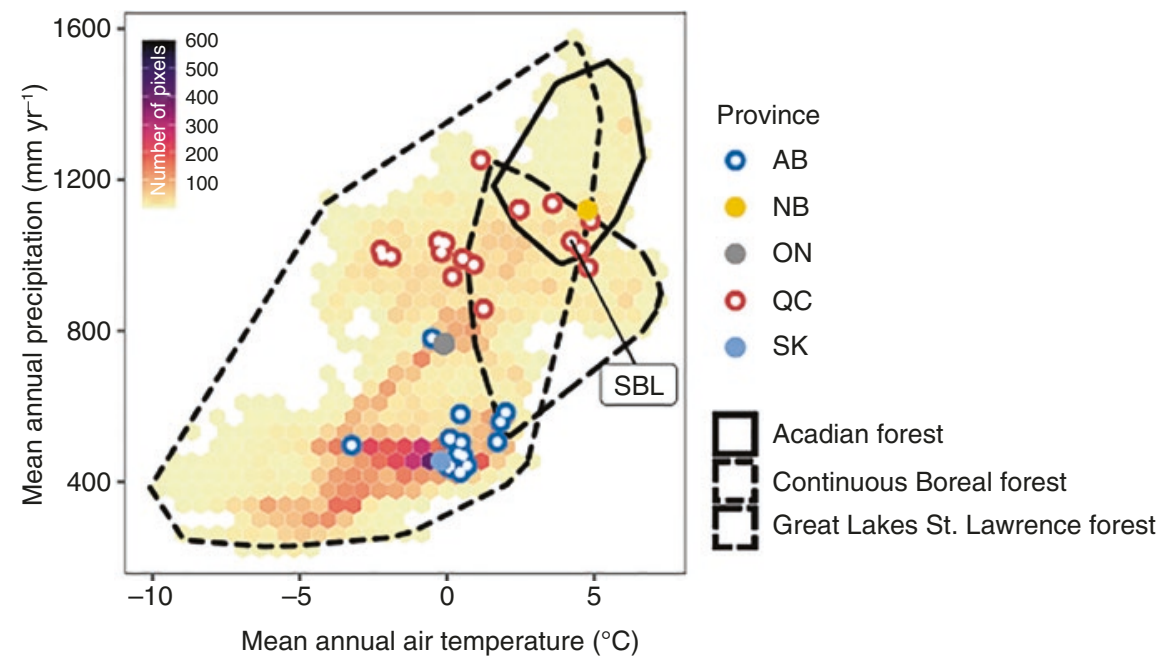

Fig. 16.3 Climate envelope of the forest types covered by the Smartforests network (color-coded dots denote the province, namely, Alberta, AB; New Brunswick, NB; Ontario, ON; Quebec, QC; Saskatchewan, SK; see also Fig. 16.1; for clarity, filled and open circles are used). Hexagons, color-coded with the density of $10^{\prime}$ resolution pixels, define the climate space of mean annual air temperature and total precipitation, as quantified using the WorldClim dataset (Fick and Hijmans 2017). Polygons show the specific forest types, as classified by Rowe 1972, which overlap the Smartforests network of sites. The case study used here to illustrate the implemented Smartforests approach is also highlighted (Station de biologie des Laurentides; SBL) 
hardwoods to the boreal region along an East-West moisture gradient across the country, with mean annual total precipitation ranging from $380 \mathrm{~mm}$ in the West to $1252 \mathrm{~mm}$ in the East (Fig. 16.3). The latitudinal North-South gradient includes temperate shade-tolerant hardwood forests in southern Quebec, mixed temperate and temperate-boreal transition zone forests, as well as mixedwood and black spruce boreal forests in the Abitibi region. The East-West moisture gradient extends from the Acadian forest in New Brunswick to boreal forest plots on the North Shore of Quebec and to a series of boreal plots across Ontario, Manitoba, Saskatchewan, and Alberta. The wide range of environmental conditions and forest types covered by this network allows us to quantify forest dynamics, health, and resilience at the forest stand level and assess climate-change impacts by combining insights from the temperate, temperate/boreal transition, and boreal forest zones. The Smartforests network includes long-term monitoring sites, with more than a decade of detailed forest monitoring, as well as recently established research sites. The spatial and temporal gradient being covered by this network allows us to detect long-term effects of small changes in productivity or community relationships, including the influence of extreme events that may only affect a small number of sites, as a result of inter- and intraspecific differences in tree species, as well as adaptations of tree functioning to prevailing environmental conditions, e.g., species-specific responses of tree water use in humid forest stands of Eastern Canada (Oogathoo et al. 2020) vs. responses of the same species in drier sites in Central Canada (Pappas et al. 2018). Description of the design and efficacy of a network of observational plots across European mountain regions is presented in Chap. 5 of this book (Pretzsch et al. 2021).

\subsection{Climate-Smart Forestry with High-Precision Monitoring Plots}

\subsubsection{From Forest Function to Forest Health and Resilience}

Robust quantification of forest function including below- and aboveground components with processes occurring at cell, organism, and ecosystem levels provides the basis for assessing forest health and resilience to ongoing environmental change (Reyer et al. 2015). For example, tree growth is an indicator of tree age and vitality that is influenced by ontogeny, local competition, and climate (Dobbertin 2005). Temporal data on tree growth (e.g., annual tree ring widths, seasonal dendrometerderived growth signals) can be used to characterize tree performance, vulnerability, and resilience to environmental changes over time (Lloret et al. 2011; Rogers et al. 2018; Pappas et al. 2020b). Moreover, tree water use and storage are indicators of drought-induced tree mortality risk (Martinez-Vilalta et al. 2018), and when combined with tree growth measurements, interspecific differences in species resilience could be quantified (Pappas et al. 2020b). Combining tree-level ecophysiological 
observations with remote sensing products covering forest landscapes provides a large-scale perspective of forest health that is useful in deriving early warning signals of critical transitions in forested ecosystems, e.g., drought-induced tree mortality (Camarero et al. 2015; Rogers et al. 2018; Cailleret et al. 2019). Discussion on how to implement tree-based monitoring platforms and large-scale forest observations is presented in Chaps. 10 and 11 of this book (respectively, Tognetti et al. 2021; Torresan et al. 2021). Thus, the Smartforests toolbox is geared to develop a quantitative and process-based understanding linking forest function under recent past and present environmental conditions with forest health and resilience to climate change using mechanistic understanding and modelling tools to predict future forest responses to environmental stressors.

\subsubsection{Modelling and Adapting Forests to Climate Change}

A comprehensive understanding of the interactions between forest dynamics, climate change, and management requires the use of simulation models optimized on robust data. Current tools employed by managers are still strongly influenced by the idea that forest ecosystems are at equilibrium with environmental conditions and tend to ignore the effects of changing environmental factors and vegetation acclimation and adaptation. The data collected under Smartforests are tailored to provide the necessary information to parameterize and validate state-of-the-art processbased models of forest growth and vegetation functioning (Fatichi et al. 2016; Prentice et al. 2015; Gennaretti et al. 2017). Process-based models facilitate prognostic simulations with a scenario analysis approach to evaluate, both at stand and landscape level, the benefits, compromises, and uncertainties associated with different management strategies and climate change scenarios. Simulation models constitute a relevant approach to investigate the dynamics, function, and structure of forests at scales that may be difficult to capture via experimental field research alone.

In addition, models are powerful tools for evaluating the long-term consequences of variation in baseline conditions and management strategies on forests at different spatial scales (Elkin et al. 2013; Bugmann et al. 2019). This approach is becoming more relevant with the acknowledged need to develop management strategies that will ensure that forest ecosystems maintain the variety of services on which our society depends, despite uncertainties associated with rapidly changing ecological, climatic, and economic conditions (Albrich et al. 2020). Managers and decisionmakers already rely on simulation models, for example, to determine annual allowable cut levels. In many regions of Canada, forests are now being managed as ecosystems rather than just for fiber. While this approach is a large step forward in that it considers multiple values, it still often fails to consider changing forest conditions and natural disturbance regimes. As such, the effects of climate change are not considered in simulation models used for determining the annual allowable cut, which may overestimate timber supply. There is, therefore, an urgent need to adapt current simulation models and develop new models that better integrate uncertainty in resource availability, risk management in planning processes, and the multiple 
spatial and temporal scales over which climate change influences forests (Boucher et al. 2018; Boulanger et al. 2019; Gauthier et al. 2015; Mina et al. 2020).

Models that represent key ecosystem processes and are parameterized, calibrated, and validated with multivariate observations from the Smartforests network can be used to test and compare scenarios for developing adaptive forest management strategies. The data collected with Smartforests will contribute to the improvement of parameter estimates and to the accuracy of the processes being modelled, such as tree water use and growth, tree mortality, plant phenology, plant nutrition, natural disturbance dynamics, plant succession, plant inter- and intraspecific interactions, plant-microbe interactions, as well as the effect of climate change on these processes. Simulation results from these models provide virtual numerical experiments which can be used to inform managers and decision-makers on the best strategies to use in order to mitigate the negative impacts of global change and to adapt to and exploit opportunities linked with future environmental conditions. The models will be crucial to evaluating the consequences of alternative management approaches under different climate scenarios and thus providing managers with means of incorporating newly acquired data into decision-making. A review of mechanistic and empirical models, which are currently available to predict forest growth, is presented in Chap. 7 of this book (Bosela et al. 2021).

\subsection{A Smartforests Case Study}

\subsubsection{Site Description}

To illustrate the Smartforests methodological approach, we used the established high-precision monitoring plots at the Station de biologie des Laurentides (SBL; $45.987 \mathrm{~N}, 74.005 \mathrm{E}$ ), which is located within the temperate hardwood forest of the Great Lakes - St. Laurent region of Quebec (Figs. 16.1 and 16.4). The SBL site is a $16.4 \mathrm{~km}^{2}$ research and teaching forest operated by the Université de Montréal (https://sbl.umontreal.ca/) and is situated in a transitional mixedwood forest within the southern Laurentians region (Fig. 16.4). The area is characterized by a continental climate with a mean annual air temperature of $5.5^{\circ} \mathrm{C}$ and total precipitation of $1050 \mathrm{~mm}$ (long-term 1980-2010 averages from meteorological observations in St. Jerome; Environment and Climate Change Canada). Overstory vegetation includes common tree species in North America's temperate, boreal, and temperate/boreal transition zone (Table 16.1). Due to its geographic position, topography, and disturbance history, the area has developed into a mosaic of tree species, with dominant species being sugar and red maple (Acer saccharum Marsh. and Acer rubrum L.) mixed with American beech (Fagus grandifolia Ehrh.), white and yellow birch (Betula papyrifera Marsh. and Betula alleghaniensis Britt.), balsam fir (Abies balsamea (L.) Mill.), and bigtooth aspen (Populus grandidentata Michx.). Patches of forest stands dominated with red oak (Quercus rubra L.) occur at the southeast edge of the SBL region, corresponding to the northern species distribution range (Fig. 16.4). Understory vegetation consists primarily of striped maple (Acer 

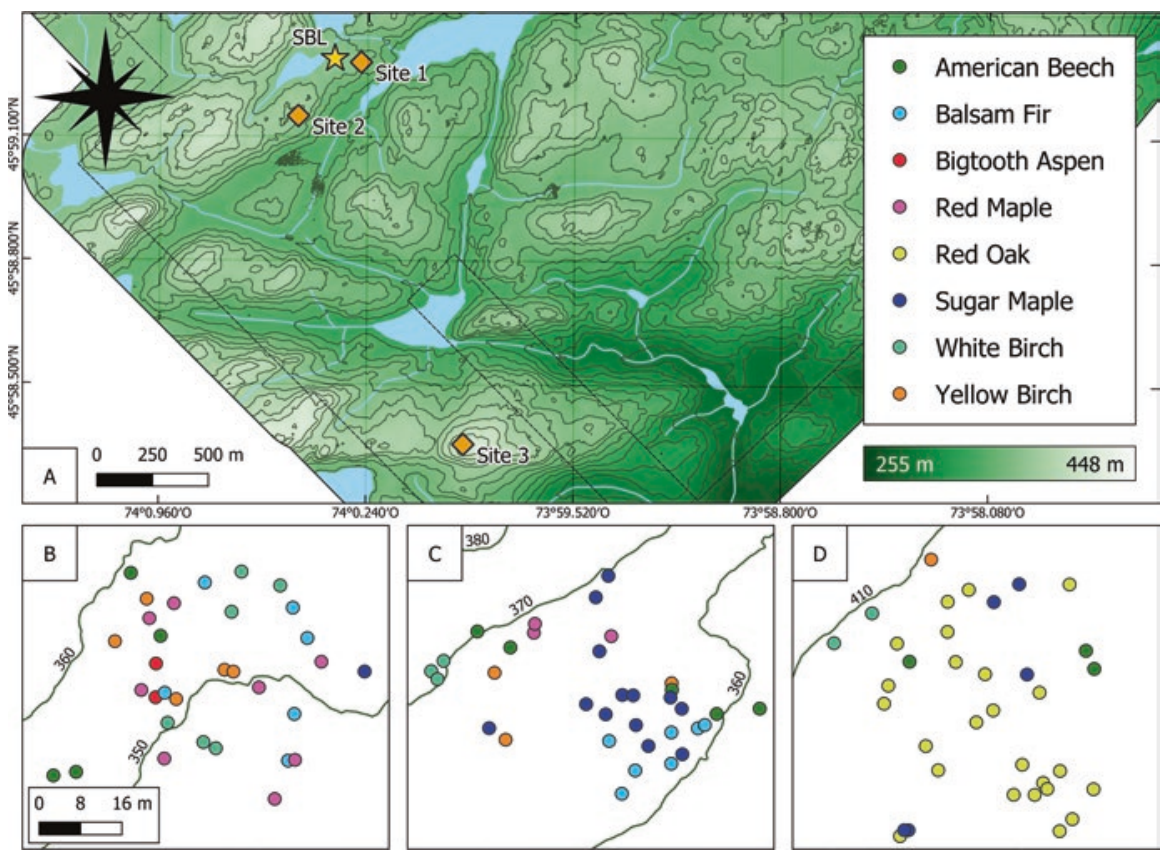

Fig. 16.4 Location of the three forest plots at the Station de biologie des Laurentides (SBL) together with the exact locations of the trees selected for continuous monitoring of stem growth and water use, color-coded according to species

pensylvanicum L.), hobblebush (Viburnum lantanoides Michx.), wood fern (Dryopteris spp.), and lycopods (Lycopodium spp.). The forest floor is a moder humus form, and most of the soils, which are thin, are well-drained Orthic FerroHumic or Humo-Ferric Podzols (Soil Classification Working Group 1998). To better capture local-scale topographic gradients and heterogeneity related to vegetation composition, three distinct forest plots were established within the SBL region for automated monitoring and campaign-based surveys (Fig. 16.4, Table 16.1). Average stand age, density, and basal area of overstory tree species (i.e., stem diameter $\geq 5 \mathrm{~cm})$ in these plots are around 80 year, $1060 \mathrm{stems} \mathrm{ha}^{-1}$ and $33 \mathrm{~m}^{2} \mathrm{ha}^{-1}$, respectively (Table 16.1).

\subsubsection{Automated Measurements of Forest Functioning}

Tree-level ecophysiological measurements are collected with automated equipment at the three forest plots at SBL and, together with concurrently recorded environmental variables (e.g., meteorological and soil conditions), are used to characterize tree and forest growth dynamics and water use (Fig. 16.2). Meteorological variables include hourly recorded rainfall, snow depth, albedo, relative humidity, air 
Table 16.1 An overview of the tree species at Station de biologie des Laurentides (SBL) selected for continuous monitoring of stem growth and water use, together with their leaf type, taxon group, wood anatomy, and stand demography (stem density and basal area for overstory trees with $\mathrm{DBH} \geq 5.0 \mathrm{~cm})$

\begin{tabular}{l|l|l|l|l|l}
\hline Species name & $\begin{array}{l}\text { Common } \\
\text { name }\end{array}$ & Leaf type & Taxon group & $\begin{array}{l}\text { Wood } \\
\text { anatomy }\end{array}$ & $\begin{array}{l}\text { Density }[\text { stems } \\
\left.\text { ha }{ }^{-1}\right] ; \\
\text { Basal area } \\
{\left[\mathrm{m}^{2} \mathrm{ha}^{-1}\right]}\end{array}$ \\
\hline Abies balsamea & Balsam fir & $\begin{array}{l}\text { Needle- } \\
\text { leaved }\end{array}$ & Gymnosperm & Tracheids & $91 ; 0.9$ \\
\hline Acer rubrum & Red maple & $\begin{array}{l}\text { Broad- } \\
\text { leaved }\end{array}$ & Angiosperm & $\begin{array}{l}\text { Diffuse- } \\
\text { porous }\end{array}$ & $152 ; 2.7$ \\
\hline Acer saccharum & Sugar maple & $\begin{array}{l}\text { Broad- } \\
\text { leaved }\end{array}$ & Angiosperm & $\begin{array}{l}\text { Diffuse- } \\
\text { porous }\end{array}$ & $315 ; 4.5$ \\
\hline alleghaniensis & Yellow birch & $\begin{array}{l}\text { Broad- } \\
\text { leaved }\end{array}$ & Angiosperm & $\begin{array}{l}\text { Diffuse- } \\
\text { porous }\end{array}$ & $24.3 ; 1.2$ \\
\hline Betula papyrifera & White birch & $\begin{array}{l}\text { Broad- } \\
\text { leaved }\end{array}$ & Angiosperm & $\begin{array}{l}\text { Diffuse- } \\
\text { porous }\end{array}$ & $67 ; 5.6$ \\
\hline Quercus rubra & Red oak & $\begin{array}{l}\text { Broad- } \\
\text { leaved }\end{array}$ & Angiosperm & Ring-porous \\
beech & porous & $224 ; 16.2$ \\
\hline
\end{tabular}

temperature (above and below the canopy), wind speed and direction, and solar radiation, while soil conditions are characterized by hourly measurements of soil volumetric water content (VWC), water potential, and temperature recorded at a depth of approximately $10 \mathrm{~cm}$ (Fig. 16.5; Spectrum Technologies, Aurora, IL, US). Across the study region, 48 micro-stations are deployed. For each micro-station, two replicates of two soil variables are included (i.e., soil temperature and VWC or soil temperature and water potential) for a robust characterization of local-scale environmental heterogeneity (Fig. 16.5).

Tree ecophysiological monitoring includes: (1) sap flow measurements with both custom-made thermal dissipation sensors $(20 \mathrm{~mm}$ long stainless-steel probes, with a 2 mm diameter; Granier 1987; Lu et al. 2004; Pappas et al. 2018) and commercial sensors (3-N, East 30, Pullman, WA, USA) measuring sap flow with the heat ratio method (Burgess et al. 2001) and (2) stem radius change measurements with two types of high-frequency and precision stem dendrometers (DC3, Ecomatik, Munich, Germany; DRL26C, Environmental Measuring Systems, Brno, Czech Republic). More than 100 trees are instrumented with sap flow and stem dendrometers in the three study plots, and all dominant tree species in the area are represented in the measurements being conducted (Fig. 16.4). This large sample size allows for detailed quantification of temporal dynamics in tree growth and water use and their inter- and intraspecific differences as well as for upscaling estimates to the forest stand level (Fig. 16.2). Measuring sap flow with two different methods allows us to infer sap flow at different sapwood depths and to derive species-specific radial profiles of sap ascent in tree stems (Fig. 16.6). Such information not only is useful for 
a Rainfall

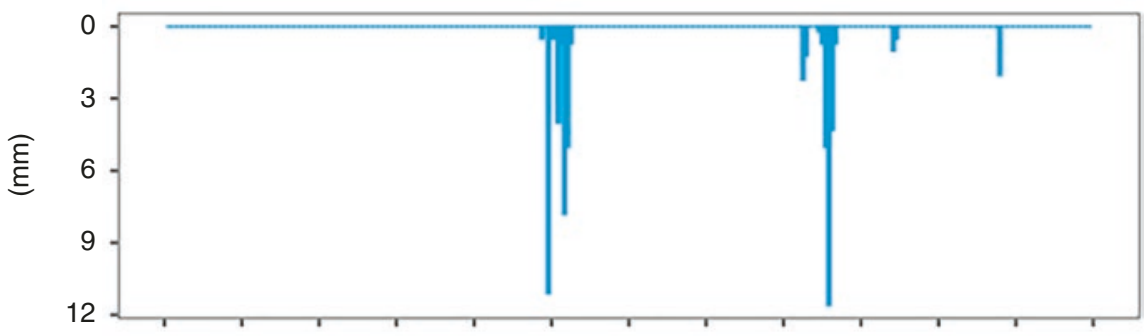

b Vapour pressure deficit

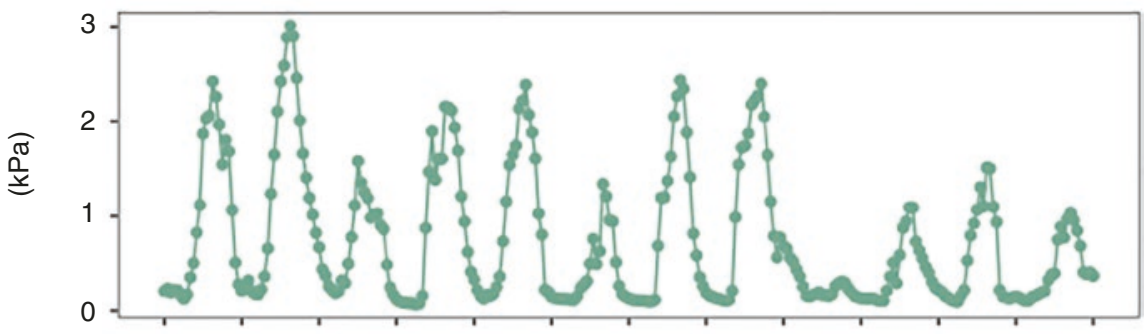

c Volumetric water content

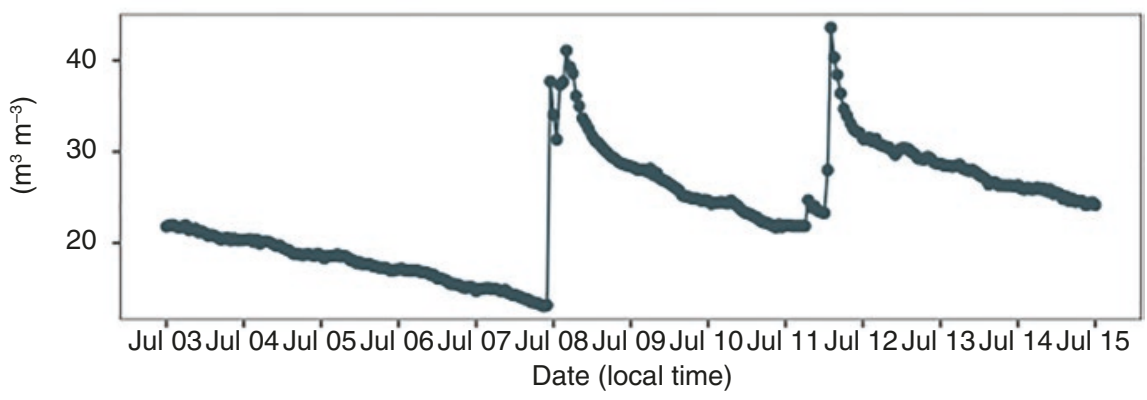

Fig. 16.5 Hourly time series for key meteorological and soil variables at the Station de biologie des Laurentides (SBL, Site 2; Fig. 16.4) for the period July 3 to July 15, 2020. Rainfall events (subplot a) resulted in drops in daytime vapor pressure deficit (subplot b) and concurrently increased soil water content (subplot c)

pinpointing interspecific differences in stem hydraulics and water use but also allows for robust transpiration estimates at the forest stand level (Berdanier et al. 2016). Further, combining constant heat (thermal dissipation method) and pulsebased (heat ratio method) sap flow measuring techniques allows us to minimize uncertainties related to method-specific assumptions and limitations (Steppe et al. 2010; Rabbel et al. 2016; Peters et al. 2018, 2020; Flo et al. 2019). By doing so, tree water use and transpiration rates can be assessed in terms of both temporal dynamics and absolute rates. Moreover, when combining tree-level data using different measuring techniques with forest stand characteristics (e.g., stem density) and 

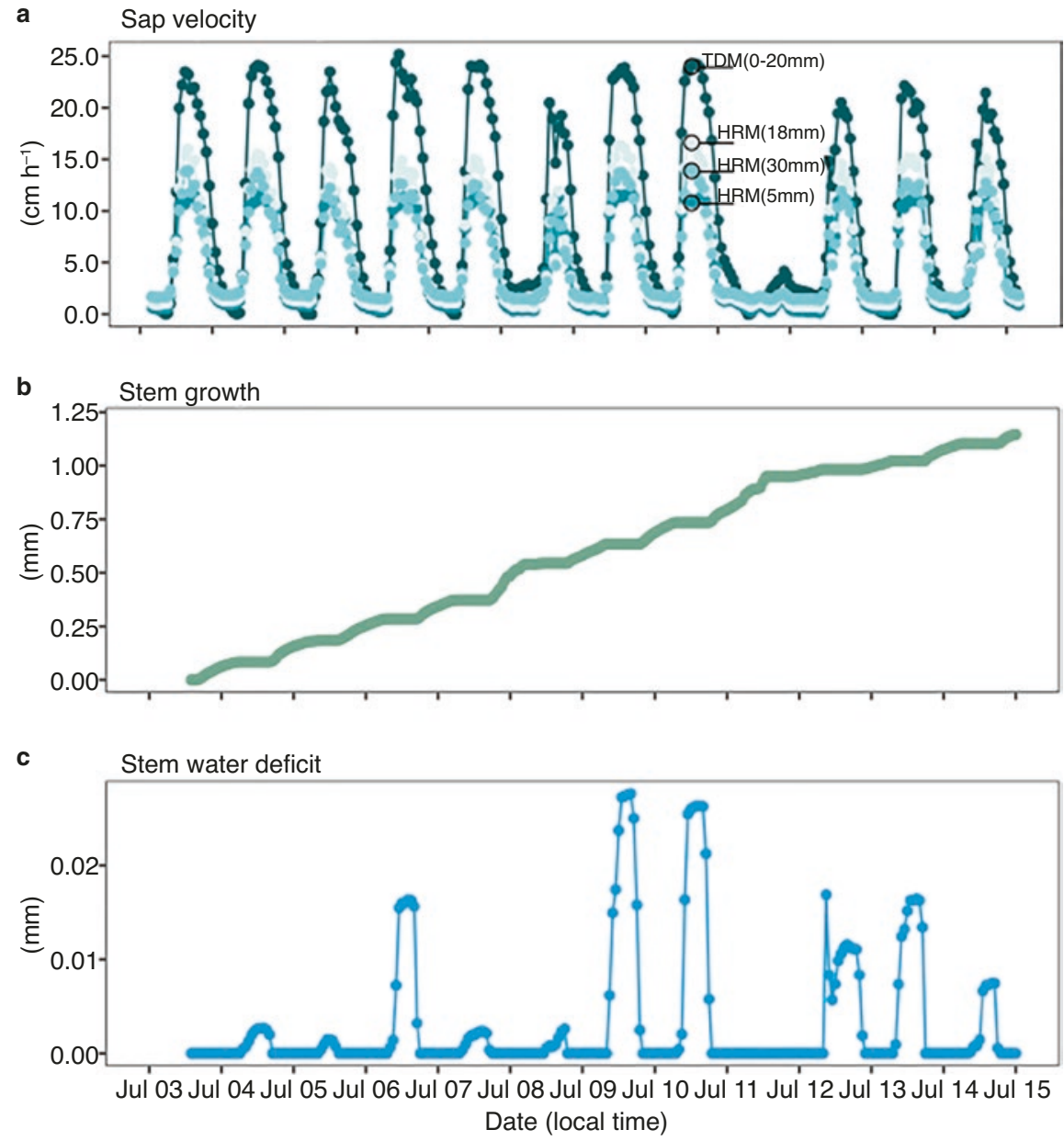

Fig. 16.6 Hourly time series of concurrently recorded ecophysiological variables using sap flow and dendrometer sensors affixed to the stem of an American beech (Fagus grandifolia) with $\mathrm{DBH}=15.1 \mathrm{~cm}$ and sapwood depth, $S_{\mathrm{d}}=3.9 \mathrm{~cm}$, at the Station de biologie des Laurentides (SBL, Site 2; Fig. 16.4) for the period July 3 to July 15, 2020. Continuous ecophysiological monitoring includes sap velocity (subplot a) measured with two approaches, namely, the thermal dissipation method (TDM; $20 \mathrm{~mm}$ long probes; data processed with the TREX R Package; Peters et al. 2020) and the heat ratio method (HRM; at $5 \mathrm{~mm}, 18 \mathrm{~mm}$, and $30 \mathrm{~mm}$ sapwood depths), and stem radius changes, used to derive stem growth (subplot $\mathrm{b}$ ) and stem water status (stem water deficit; subplot c) computed with the treenetproc R package (Haeni et al. 2020; Knüsel et al. 2021)

species-specific allometry (e.g., sapwood area), transpiration estimates can be derived at the forest stand level (Oishi et al. 2008; Link et al. 2014; Matheny et al. 2014; Renner et al. 2016; Hassler et al. 2018). Two different measuring techniques are also deployed for continuously monitoring stem radius changes, namely, dendrometers mounted with tangential pulling force (DRL26C) and dendrometers 
mounted with radial pressing force (DC3), thus reducing potential weaknesses of each specific technique to infer tree growth and hydraulics at a subdaily resolution (Fig. 16.6). Processing of the recorded stem radius changes is useful to empirically disentangle: (i) irreversible changes (expansion) in the stem radius as a result of tree growth and (ii) reversible stem radius changes due to water use, i.e., subdaily variations and seasonal variation in stem water storage (King et al. 2013; Zweifel et al. 2016; Pappas et al. 2018; Haeni et al. 2020; Knüsel et al. 2021). These observations, along with concurrent sap flow measurements and established theoretical models (Mencuccini et al. 2013, 2016; Chan et al. 2016), can be used to provide processbased partitioning of hydraulic-, osmotic- and growth-driven stem fluctuations, complementing the aforementioned empirical approach for processing dendrometer data. In addition, 30 motion-sensing time-lapse cameras (Wingscapes BirdCam Pro; Ebsco Industries, Birghminham, AL) are also deployed at the sites to monitor leaf phenology from bud break in the spring to leaf senescence in the fall, taking images at various times during the day throughout the year. The cameras are installed $30 \mathrm{~cm}$ from the soil surface at an angle varying from $45^{\circ}$ to $70^{\circ}$ to monitor canopies of various heights covering understory and overstory species. Tree reproduction is monitored at the scale of the whole forest domain by an automated pollen counter and particle analyzer (RapidE, Plair SA) that identifies pollen grains at the species level in real time during the whole pollination season.

\subsubsection{Campaign-Based Data Collection}

Continuous measurements with automated methods are accompanied by field surveys and observational campaigns throughout the growing season. To date, this includes surveys for detailed monitoring of forest stand demography and aboveground tree biomass. To upscale tissue- and tree-level ecophysiological observations to the forest stand, which is the spatial scale at which policy- and decision-making is typically made, we need detailed characterization of forest stand demography and species-specific allometric characteristics (Waring and Landsberg 2011). Thus, at SBL, several circular subplots were established, and tree species and their stem diameter at breast height $(1.3 \mathrm{~m}$ above the ground surface; $\mathrm{DBH}[\mathrm{cm}])$ were recorded (for trees with $\mathrm{DBH} \geq 5.0 \mathrm{~cm}$ ) and used to estimate site- and species-level stem density and basal area (Table 16.1).

In addition, during the summer 2020 field campaign, more than 350 tree cores were collected with a "biomass-oriented" design (Babst et al. 2014; Pappas et al. 2020a). The analysis of these tree cores will permit: (1) detailed characterization of species-specific sapwood allometry, a key parameter for quantitative estimates of tree- and forest-level water use and transpiration, and (2) reconstruction of forest stand's aboveground biomass increments to assess temporal variability in tree growth and the strength of the forest carbon sink (Babst et al. 2014; Pappas et al. 2020a). Moreover, when annual tree growth and biomass allocation patterns are combined with sub-annual (i.e., seasonal, daily, hourly) information on tree growth 
from the stem dendrometers, then the temporal spectrum of variability in growth can be characterized from hourly to decadal time scales. Such cross-scale characterization of species-specific growth patterns can provide novel insights into species responses to environmental change and, ultimately, offer a quantitative understanding of species-specific resilience (Pappas et al. 2020b).

\subsection{Outlook}

The resulting knowledge from this pan-Canadian Smartforests network, which is designed to encompass a broad range of forests and climates in Canada, will pave the way for the development of innovative adaptation strategies to ensure sustainable forest management and will enhance our understanding of ecosystem functioning. Within the context of sustainable forest management, identifying how these forests change with and respond to climate fluctuations will support development of strategies to preserve economic and non-economic ecosystem services. The Smartforests network and the integration of site-specific measurements with largerscale remote sensing products and model outputs will serve to identify early warning signals of forest responses to either subtle changes in climate or extreme events. In doing so, forest managers will be able to react quickly to develop adaptation strategies. Moreover, research across the Smartforests network will provide quantitative insights into the terrestrial biogeochemical cycles that will lead to constrained estimates of the strength of the forest carbon sink across Canada. Such constraints are necessary for Canada-wide estimates of forest carbon budgets and for guiding policy-making on climate change mitigation strategies. The collected observations across the Smartforests network will also contribute substantially to existing global networks of forest monitoring plots, including sap flow observations (SAPFLUXNET; Poyatos et al. 2020) and plant functional traits (TRY; Kattge et al. 2020), where Canadian forests are currently underrepresented.

\section{References}

ACIA (2005) Impacts of a warming arctic: arctic climate impact assessment. Cambridge University Press, Cambridge

Albrich K, Rammer W, Turner MG, Ratajczak Z, Braziunas KH, Hansen WD, Seidl R (2020, September) Simulating forest resilience: a review. Glob Ecol Biogeogr 29:2082-2096. https:// doi.org/10.1111/geb.13197

Allen CD, Breshears DD, McDowell NG (2015) On underestimation of global vulnerability to tree mortality and forest die-off from hotter drought in the Anthropocene. Ecosphere 6(8):art129. https://doi.org/10.1890/ES15-00203.1

Babst F, Bouriaud O, Papale D, Gielen B, Janssens IA, Nikinmaa E et al (2014) Above-ground woody carbon sequestration measured from tree rings is coherent with net ecosystem productivity at five eddy-covariance sites. New Phytol 201:1289-1303. https://doi.org/10.1111/ nph.12589 
Baldocchi D, Penuelas J (2019) The physics and ecology of mining carbon dioxide from the atmosphere by ecosystems. Glob Chang Biol 25(4):1191-1197. https://doi.org/10.1111/gcb.14559

Berdanier AB, Miniat CF, Clark JS (2016) Predictive models for radial sap flux variation in coniferous, diffuse-porous and ring-porous temperate trees. Tree Physiol 36:932-941. https://doi. org/10.1093/treephys/tpw027

Bosela M, Merganičová K, Torresan C, et al (2021) Modelling future growth of mountain forests under changing environments. In: Managing Forest Ecosystems, Vol. 40, Tognetti R, Smith M, Panzacchi P (Eds): Climate-Smart Forestry in Mountain Regions. Springer Nature, Switzerland, AG

Boucher D, Boulanger Y, Aubin I, Bernier PY, Beaudoin A, Guindon L, Gauthier S (2018) Current and projected cumulative impacts of fire, drought, and insects on timber volumes across Canada. Ecol Appl 28(5):1245-1259. https://doi.org/10.1002/eap.1724

Boulanger Y, Arseneault D, Boucher Y, Gauthier S, Cyr D, Taylor AR et al (2019) Climate change will affect the ability of forest management to reduce gaps between current and presettlement forest composition in southeastern Canada. Landsc Ecol 34(1):159-174. https://doi. org/10.1007/s10980-018-0761-6

Bowditch E, Santopuoli G, Binder F, del Río M, La Porta N, Kluvankova T et al (2020) What is climate-smart forestry? A definition from a multinational collaborative process focused on mountain regions of Europe. Ecosyst Serv 43(7):101113. https://doi.org/10.1016/j. ecoser.2020.101113

Brandt JP, Flannigan MD, Maynard DG, Thompson ID, Volney WJA (2013) An introduction to Canada's boreal zone: ecosystem processes, health, sustainability, and environmental issues. Environ Rev 21(4):207-226. https://doi.org/10.1139/er-2013-0040

Brecka AFJ, Boulanger Y, Searle EB, Taylor AR, Price DT, Zhu Y et al (2020) Sustainability of Canada's forestry sector may be compromised by impending climate change. For Ecol Manag 474(July):118352. https://doi.org/10.1016/j.foreco.2020.118352

Bugmann H, Seidl R, Hartig F, Bohn F, Brůna J, Cailleret M et al (2019) Tree mortality submodels drive simulated long-term forest dynamics: assessing 15 models from the stand to global scale. Ecosphere 10(2). https://doi.org/10.1002/ecs2.2616

Burgess SSO, Adams MA, Turner NC, Beverly CR, Ong CK, Khan AAH, Bleby TM (2001) An improved heat pulse method to measure low and reverse rates of sap flow in woody plants. Tree Physiol 21(15): 1157

Cailleret M, Dakos V, Jansen S, Robert EMR, Aakala T, Amoroso MM et al (2019) Early-warning signals of individual tree mortality based on annual radial growth. Front Plant Sci 9(1):1-14. https://doi.org/10.3389/fpls.2018.01964

Camarero JJ, Gazol A, Sangüesa-Barreda G, Oliva J, Vicente-Serrano SM (2015) To die or not to die: early warnings of tree dieback in response to a severe drought. J Ecol 103(1):44-57. https://doi.org/10.1111/1365-2745.12295

Chan T, Hölttä T, Berninger F, Mäkinen H, Nöjd P, Mencuccini M, Nikinmaa E (2016) Separating water-potential induced swelling and shrinking from measured radial stem variations reveals a cambial growth and osmotic concentration signal. Plant Cell Environ 39(2):233-244. https:// doi.org/10.1111/pce.12541

Chen L, Huang J-G, Alam SA, Zhai L, Dawson A, Stadt KJ, Comeau PG (2017) Drought causes reduced growth of trembling aspen in western Canada. Glob Chang Biol:1-15. https://doi. org/10.1111/gcb.13595

Clemmensen KE, Bahr A, Ovaskainen O, Dahlberg A, Ekblad A, Wallander H et al (2013) Roots and associated fungi drive long-term carbon sequestration in boreal forest. Science 339(3):1615-1618. https://doi.org/10.1016/b978-0-408-01434-2.50020-6

Cook BI, Smerdon JE, Seager R, Coats S (2014) Global warming and 21st century drying. Clim Dyn:1-21. https://doi.org/10.1007/s00382-014-2075-y

Cortini F, Comeau PG, Strimbu VC, Hogg EH(T), Bokalo M, Huang S (2017) Survival functions for boreal tree species in northwestern North America. For Ecol Manag 402:177-185. https:// doi.org/10.1016/j.foreco.2017.06.036 
D’Orangeville L, Duchesne L, Houle D, Kneeshaw D, Côté B, Pederson N (2016) Northeastern North America as a potential refugium for boreal forests in awarming climate. Science 352(6292):1452-1455. https://doi.org/10.1017/CBO9781107415324.004

D’Orangeville L, Houle D, Duchesne L, Phillips RP, Bergeron Y, Kneeshaw D (2018) Beneficial effects of climate warming on boreal tree growth may be transitory. Nat Commun 9(1):1-10. https://doi.org/10.1038/s41467-018-05705-4

Dai A (2012) Increasing drought under global warming in observations and models. Nat Clim Chang 2(8):1-7. https://doi.org/10.1038/nclimate1633

DeSoto L, Cailleret M, Sterck F, Jansen S, Kramer K, Robert EMR et al (2020) Low growth resilience to drought is related to future mortality risk in trees. Nat Commun 11(1):1-9. https://doi. org/10.1038/s41467-020-14300-5

Dobbertin M (2005) Tree growth as indicator of tree vitality and of tree reaction to environmental stress: a review. Eur J For Res 124(4):319-333. https://doi.org/10.1007/s10342-005-0085-3

Elkin C, Gutiérrez AG, Leuzinger S, Manusch C, Temperli C, Rasche L, Bugmann H (2013) A $2{ }^{\circ} \mathrm{C}$ warmer world is not safe for ecosystem services in the European Alps. Glob Chang Biol:1-14. https://doi.org/10.1111/gcb.12156

Fatichi S, Pappas C, Ivanov VY (2016) Modeling plant-water interactions: an ecohydrological overview from the cell to the global scale. Wiley Interdiscip Rev Water 3(3):327-368. https:// doi.org/10.1002/wat2.1125

Fatichi S, Pappas C, Zscheischler J, Leuzinger S (2019) Modelling carbon sources and sinks in terrestrial vegetation. New Phytol. https://doi.org/10.1111/nph.15451

Fick SE, Hijmans RJ (2017) WorldClim 2 : new 1-km spatial resolution climate surfaces for global land areas. Int J Climatol. https://doi.org/10.1002/joc.5086

Flo V, Martinez-Vilalta J, Steppe K, Schuldt B, Poyatos R (2019) A synthesis of bias and uncertainty in sap flow methods. Agric For Meteorol 271(3):362-374. https://doi.org/10.1016/j. agrformet.2019.03.012

Gauthier S, Bernier P, Kuuluvainen T, Shvidenko AZ, Schepaschenko DG (2015) Boreal forest health and global change. Science 349(6250):819-822. https://doi.org/10.1126/science.aaa9092

Gennaretti F, Gea-Izquierdo G, Boucher E, Berninger F, Arseneault D, Guiot J (2017) Ecophysiological modeling of photosynthesis and carbon allocation to the tree stem in the boreal forest. Biogeosciences 14(21):4851-4866. https://doi.org/10.5194/bg-14-4851-2017

Girardin MP, Hogg EH, Bernier PY, Kurz WA, Guo XJ, Cyr G (2016) Negative impacts of high temperatures on growth of black spruce forests intensify with the anticipated climate warming. Glob Chang Biol 22(2):627-643. https://doi.org/10.1111/gcb.13072

Granier A (1987) Evaluation of transpiration in a Douglas-fir stand by means of sap flow measurements. Tree Physiol 3(4):309-320. https://doi.org/10.1093/treephys/3.4.309

Haeni M, Wilhelm M, Peters RL, Zweifel R (2020) Treenetproc - clean, process and visualise dendrometer data. $\mathrm{R}$ package version 0.1.4. Github repository: https://github.com/treenet/ treenetproc

Hassler SK, Weiler M, Blume T (2018) Tree-, stand- and site-specific controls on landscapescale patterns of transpiration. Hydrol Earth Syst Sci 22(1):13-30. https://doi.org/10.5194/ hess-22-13-2018

Held IM, Soden BJ (2006) Robust responses of the hydrologic cycle to global warming. J Clim 19:5686-5699. https://doi.org/10.1175/JCLI3990.1

Hogg EH, Brandt JP, Michaelian M (2008) Impacts of a regional drought on the productivity, dieback, and biomass of western Canadian aspen forests. Can J For Res 38(6):1373-1384. https:// doi.org/10.1139/X08-001

Hogg EH, Barr AG, Black TA (2013) A simple soil moisture index for representing multi-year drought impacts on aspen productivity in the western Canadian interior. Agric For Meteorol 178-179:173-182. https://doi.org/10.1016/j.agrformet.2013.04.025

Huang JA, Tardif JC, Bergeron Y, Denneler B, Berninger F, Girardin MP (2010) Radial growth response of four dominant boreal tree species to climate along a latitudinal gradient in the eastern Canadian boreal forest. Glob Chang Biol 16(2):711-731. https://doi. org/10.1111/j.1365-2486.2009.01990.x 
IPCC (2013) In: Stocker TF, Qin D, Plattner G-K, Tignor M, Allen SK, Boschung J et al (eds) Climate change 2013: the physical science basis. Contribution of working group I to the fifth assessment report of the intergovernmental panel on climate change. Cambridge University Press, Cambridge/New York

Kattge J, Bönisch G, Díaz S, Lavorel S, Prentice IC, Leadley P et al (2020) TRY plant trait database - enhanced coverage and open access. Glob Chang Biol 26(1):119-188. https://doi. org/10.1111/gcb.14904

Kayler ZE, De Boeck HJ, Fatichi S, Grünzweig JM, Merbold L, Beier C et al (2015) Experiments to confront the environmental extremes of climate change. Front Ecol Environ 13(5):219-225. https://doi.org/10.1890/140174

King G, Fonti P, Nievergelt D, Büntgen U, Frank D (2013) Climatic drivers of hourly to yearly tree radius variations along a $6^{\circ} \mathrm{C}$ natural warming gradient. Agric For Meteorol 168:36-46. https:// doi.org/10.1016/j.agrformet.2012.08.002

Knüsel S, Peters RL, Haeni M, Wilhelm M, Zweifel R (2021) Processing and extraction of seasonal tree physiological parameters from stem radius time series. Forests 12(6):1-14. https:// doi.org/10.3390/f12060765

Landuyt D, De Lombaerde E, Perring MP, Hertzog LR, Ampoorter E, Maes SL et al (2019) The functional role of temperate forest understorey vegetation in a changing world. Glob Chang Biol 25(11):3625-3641. https://doi.org/10.1111/gcb.14756

Le Quéré C, Barbero L, Hauck J, Andrew RM, Canadell JG, Sitch S, Korsbakken JI (2018) Global carbon budget 2018. Earth Syst Sci Data 10(4):2141-2194

Link P, Simonin K, Maness H, Oshun J, Dawson T, Fung I (2014) Species differences in the seasonality of evergreen tree transpiration in a Mediterranean climate: analysis of multiyear, half-hourly sap flow observations. Water Resour Res 50:1-26. https://doi.org/10.1002/2013WR014023. Received

Lloret F, Keeling EG, Sala A (2011) Components of tree resilience: effects of successive lowgrowth episodes in old ponderosa pine forests. Oikos 120(12):1909-1920. https://doi. org/10.1111/j.1600-0706.2011.19372.x

Lu P, Urban L, Zhao P (2004) Granier's thermal dissipation probe (TDP) method for measuring sap flow in trees: theory and practice. Acta Bot Sin 46(6):631-646. https://doi.org/316-646

Luyssaert S, Schulze E-D, Börner A, Knohl A, Hessenmöller D, Law BE et al (2008) Old-growth forests as global carbon sinks. Nature 455(7210):213-215. https://doi.org/10.1038/nature07276

Martinez-Vilalta J, Anderegg WRL, Sapes G, Sala A (2018) Greater focus on water pools may improve our ability to understand and anticipate drought-induced mortality in plants. New Phytol 12:0-3. https://doi.org/10.1111/nph.15644

Mastrotheodoros T, Pappas C, Molnar P, Burlando P, Manoli G, Parajka J et al (2020) More green and less blue water in the Alps during warmer summers. Nat Clim Chang 10(2):155-161. https://doi.org/10.1038/s41558-019-0676-5

Matheny A, Bohrer G, Vogel CS, Morin T, He L, de Frasson RPM et al (2014) Species-specific transpiration responses to intermediate disturbance in a northern hardwood forest. J Geophys Res Biogeo 119(12):2292-2311. https://doi.org/10.1002/2014JG002804.Received

Mencuccini M, Hölttä T, Sevanto S, Nikinmaa E (2013) Concurrent measurements of change in the bark and xylem diameters of trees reveal a phloem-generated turgor signal. New Phytol 198(4):1143-1154. https://doi.org/10.1111/nph.12224

Mencuccini M, Salmon Y, Mitchell P, Hölttä T, Choat B, Meir P et al (2016) An empirical method that separates irreversible stem radial growth from bark water content changes in trees: theory and case studies. Plant Cell Environ:290-303. https://doi.org/10.1111/pce.12863

Mencuccini M, Manzoni S, Christoffersen B (2019) Modelling water fluxes in plants: from tissues to biosphere. New Phytol 222(3):1207-1222. https://doi.org/10.1111/nph.15681

Michaelian M, Hogg EH, Hall RJ, Arsenault E (2011) Massive mortality of aspen following severe drought along the southern edge of the Canadian boreal forest. Glob Chang Biol 17(6):2084-2094. https://doi.org/10.1111/j.1365-2486.2010.02357.x 
Mina M, Messier C, Duveneck M, Fortin M-J, Aquilué N (2020) Network analysis can guide resilience-based management in forest landscapes under global change. Ecol Appl 00(00):e02221. https://doi.org/10.1002/eap.2221

Navarro L, Morin H, Bergeron Y, Girona MM (2018) Changes in spatiotemporal patterns of 20th century spruce budworm outbreaks in eastern Canadian boreal forests. Front Plant Sci 9(December):1-15. https://doi.org/10.3389/fpls.2018.01905

Novick KA, Ficklin DL, Stoy PC, Williams CA, Bohrer G, Oishi AC et al (2016) The increasing importance of atmospheric demand for ecosystem water and carbon fluxes. Nat Clim Chang 1(9):1-5. https://doi.org/10.1038/nclimate3114

Oishi AC, Oren R, Stoy PC (2008) Estimating components of forest evapotranspiration: a footprint approach for scaling sap flux measurements. Agric For Meteorol 148(11):1719-1732. https:// doi.org/10.1016/j.agrformet.2008.06.013

Oogathoo S, Houle D, Duchesne L, Kneeshaw D (2020) Vapour pressure deficit and solar radiation are the major drivers of transpiration of balsam fir and black spruce tree species in humid boreal regions, even during a short-term drought. Agric For Meteorol 291(10):108063. https:// doi.org/10.1016/j.agrformet.2020.108063

Pan Y, Birdsey RA, Fang J, Houghton R, Kauppi PE, Kurz WA et al (2011) A large and persistent carbon sink in the world's forests. Science 333(6045):988-993. https://doi.org/10.1126/ science. 1201609

Pappas C, Matheny AM, Baltzer JL, Barr A, Black TA, Bohrer G et al (2018) Boreal tree hydrodynamics: asynchronous, diverging, yet complementary. Tree Physiol 38(7):953-964. https:// doi.org/10.1093/treephys/tpy043

Pappas C, Maillet J, Rakowski S, Baltzer JL, Barr AG, Black TA et al (2020a) Aboveground tree growth is a minor and decoupled fraction of boreal forest carbon input. Agric For Meteorol 290(9):0-1. https://doi.org/10.1016/j.agrformet.2020.108030

Pappas C, Peters RL, Fonti P (2020b) Linking variability of tree water use and growth with species resilience to environmental changes. Ecography 43(9):1386-1399. https://doi.org/10.1111/ ecog.04968

Peng C, Ma Z, Lei X, Zhu Q, Chen H, Wang W et al (2011) A drought-induced pervasive increase in tree mortality across Canada's boreal forests. Nat Clim Chang 1(12):467-471. https://doi. org/10.1038/nclimate1293

Peters RL, Fonti P, Frank DC, Poyatos R, Pappas C, Kahmen A et al (2018) Quantification of uncertainties in conifer sap flow measured with the thermal dissipation method. New Phytol. https://doi.org/10.1111/nph.15241

Peters RL, Pappas C, Hurley AG, Poyatos R, Flo V, Zweifel R et al (2020) Assimilate, process, and analyse thermal dissipation sap flow data using the TREX R package. Methods Ecol Evol:1-9. https://doi.org/10.1111/2041-210x.13524

Poyatos R, Granda V, Flo V, Adams MA, Adorján B, Aguadé D et al (2020) Global transpiration data from sap flow measurements: the SAPFLUXNET database. Earth Syst Sci Data Discuss 2020(10):1-57. https://doi.org/10.5194/essd-2020-227

Prentice IC, Liang X, Medlyn BE, Wang YP (2015) Reliable, robust and realistic: the three R's of next-generation land-surface modelling. Atmos Chem Phys 15(10):5987-6005. https://doi. org/10.5194/acp-15-5987-2015

Pretzsch H, Hilmers T, Uhl E, et al (2021) Efficacy of trans-geographic observational network design for revelation of growth pattern in mountain forests across Europe. In: Managing Forest Ecosystems, Vol. 40, Tognetti R, Smith M, Panzacchi P (Eds): Climate-Smart Forestry in Mountain Regions. Springer Nature, Switzerland, AG

Price DT, Alfaro RI, Brown KJ, Flannigan MD, Fleming RA, Hogg EH et al (2013) Anticipating the consequences of climate change for Canada' s boreal forest ecosystems. Environ Rev 365(12):322-365

Pugh TAM, Arneth A, Kautz M, Poulter B, Smith B (2019) Important role of forest disturbances in the global biomass turnover and carbon sinks. Nat Geosci 12(9):730-735. https://doi. org/10.1038/s41561-019-0427-2 
Pureswaran DS, De Grandpré LD, Paré D, Taylor A, Barrette M, Morin H et al (2015) Climateinduced changes in host tree-insect phenology may drive ecological state-shift in boreal forests. Ecology 96(6):1480-1491. https://doi.org/10.1890/13-2366.1

Rabbel I, Diekkrüger B, Voigt H, Neuwirth B (2016) Comparing $\Delta$ Tmax determination approaches for Granier-based sapflow estimations. Sensors 16(12):1-16. https://doi.org/10.3390/ s16122042

Renner M, Hassler SK, Blume T, Weiler M, Hildebrandt A, Guderle M et al (2016) Dominant controls of transpiration along a hillslope transect inferred from ecohydrological measurements and thermodynamic limits. Hydrol Earth Syst Sci 20:2063-2083. https://doi.org/10.5194/ hess-2015-535

Reyer CPO, Brouwers N, Rammig A, Brook BW, Epila J, Grant RF et al (2015) Forest resilience and tipping points at different spatio-temporal scales: approaches and challenges. J Ecol 103(1):5-15. https://doi.org/10.1111/1365-2745.12337

Rogers BM, Solvik K, Hogg EH, Ju J, Masek JG, Michaelian M et al (2018) Detecting early warning signals of tree mortality in boreal North America using multiscale satellite data. Glob Chang Biol 24(6):2284-2304. https://doi.org/10.1111/gcb.14107

Rowe JS (1972) Forest regions of Canada. Canadian Forest Service Publications, Ottawa

Safranyik L, Carroll AL, Régnière J, Langor DW, Riel WG, Shore TL et al (2010) Potential for range expansion of mountain pine beetle into the boreal forest of North America. Can Entomol 142(5):415-442. https://doi.org/10.4039/n08-CPA01

Sass-Klaassen U, Fonti P, Cherubini P, Gričar J, Robert EMR, Steppe K, Bräuning A (2016) A tree-centered approach to assess impacts of extreme climatic events on forests. Front Plant Sci 7(7):1-6. https://doi.org/10.3389/fpls.2016.01069

Searle EB, Chen HYH (2017) Persistent and pervasive compositional shifts of western boreal forest plots in Canada. Glob Chang Biol 23(2):857-866. https://doi.org/10.1111/gcb.13420

Seidl R, Thom D, Kautz M, Martin-Benito D, Peltoniemi M, Vacchiano G et al (2017) Forest disturbances under climate change. Nat Clim Chang 7(6):395-402. https://doi.org/10.1038/ nclimate 3303

Soil Classification Working Group (1998) The Canadian system of soil classification. NRC Research Press, Ottawa

Soja AJ, Tchebakova NM, French NHF, Flannigan MD, Shugart HH, Stocks BJ et al (2007) Climate-induced boreal forest change: predictions versus current observations. Glob Planet Chang 56:274-296. https://doi.org/10.1016/j.gloplacha.2006.07.028

Steppe K, De Pauw DJW, Doody TM, Teskey RO (2010) A comparison of sap flux density using thermal dissipation, heat pulse velocity and heat field deformation methods. Agric For Meteorol 150(7-8):1046-1056. https://doi.org/10.1016/j.agrformet.2010.04.004

Steppe K, von der Crone JS, De Pauw DJW (2016) TreeWatch.net: a water and carbon monitoring and modeling network to assess instant tree hydraulics and carbon status. Front Plant Sci 7(7):1-8. https://doi.org/10.3389/fpls.2016.00993

Tagesson T, Schurgers G, Horion S, Ciais P, Tian F, Brandt M et al (2020) Recent divergence in the contributions of tropical and boreal forests to the terrestrial carbon sink. Nat Ecol Evol 4(2):202-209. https://doi.org/10.1038/s41559-019-1090-0

The State of Canada's Forests. Annual Report 2020 (2020) Natural Resources Canada. Canadian Forest Service, Ottawa, 88 p. https://cfs.nrcan.gc.ca/publications?id=40219\&lang=en_CA

Tognetti R, Valentini R, Belelli Marchesini L, Gianelle D, Panzacchi P, Marshall JD (2021) Continuous monitoring of tree responses to climate change for smart forestry - a cybernetic web of trees. In: Managing Forest Ecosystems, Vol. 40, Tognetti R, Smith M, Panzacchi P (Eds): Climate-Smart Forestry in Mountain Regions. Springer Nature, Switzerland, AG

Torresan C, Luyssaert S, Filippa G, Imangholiloo M, Gaulton R (2021) Remote sensing technologies for assessing climate-smart criteria in mountain forests. In: Managing Forest Ecosystems, Vol. 40, Tognetti R, Smith M, Panzacchi P (Eds): Climate-Smart Forestry in Mountain Regions. Springer Nature, Switzerland, AG 
Trumbore S, Brando P, Hartmann H (2015) Forest health and global change. Science 349(6250):814-818. https://doi.org/10.1126/science.aac6759

Verkerk PJ, Costanza R, Hetemäki L, Kubiszewski I, Leskinen P, Nabuurs GJ et al (2020) Climate-smart forestry: the missing link. Forest Policy Econ 115(4). https://doi.org/10.1016/j. forpol.2020.102164

Vicca S, Luyssaert S, Peñuelas J, Campioli M, Chapin FS, Ciais P et al (2012) Fertile forests produce biomass more efficiently. Ecol Lett 15(6):520-526. https://doi. org/10.1111/j.1461-0248.2012.01775.x

Walker AP, De Kauwe MG, Bastos A, Belmecheri S, Georgiou K, Keeling RF et al (2020) Integrating the evidence for a terrestrial carbon sink caused by increasing atmospheric $\mathrm{CO}$. New Phytol. https://doi.org/10.1111/nph.16866

Waring RH, Landsberg JJ (2011) Generalizing plant-water relations to landscapes. J Plant Ecol 4(1-2):101-113. https://doi.org/10.1093/jpe/rtq041

Zweifel R, Haeni M, Buchmann N, Eugster W (2016) Are trees able to grow in periods of stem shrinkage? New Phytol 211(3):839-849. https://doi.org/10.1111/nph.13995

Open Access This chapter is licensed under the terms of the Creative Commons Attribution 4.0 International License (http://creativecommons.org/licenses/by/4.0/), which permits use, sharing, adaptation, distribution and reproduction in any medium or format, as long as you give appropriate credit to the original author(s) and the source, provide a link to the Creative Commons license and indicate if changes were made.

The images or other third party material in this chapter are included in the chapter's Creative Commons license, unless indicated otherwise in a credit line to the material. If material is not included in the chapter's Creative Commons license and your intended use is not permitted by statutory regulation or exceeds the permitted use, you will need to obtain permission directly from the copyright holder. 